\title{
POMEN DEJAVNEGA DRŽAVLJANSTVA IN DRŽAVLJANSKE VZGOJE V ČASU MIGRACIJ IN BEGUINSKE KRIZE V EVROPI
}

\section{POVZETEK}

V prispevku obravnavamo koncipiranje državljanske vzgoje in dejavnega državljanstva v izobraževanju odraslih v vse bolj raznoliki in pluralni evropski družbi, ki se sooča z množičnim prihodom beguncev in migrantov. V izhodišče razprave postavljamo dva koncepta državljanske vzgoje: »državljanstvo kot status « in »državljanstvo kot prakso«. Pri opredelitvi prvega izhajamo iz Habermasovega pojmovanja demokracije in javne sfere ter pokažemo, da je državljanska vzgoja v integracijskih izobraževalnih programih povezana predvsem s prilagoditvijo prišlekov obstoječemu liberalnodemokratskemu družbenemu redu, torej z njeno socializacijsko funkcijo. V nasprotju s to konceptualizacijo državljanske vzgoje ter opirajoč se na pojmovanje demokracije in političnega, kot sta ga razvila Mouffejeva in Rancière, dokazujemo tezo, da sta državljanska vzgoja in dejavno državljanstvo bistveno povezana s prakticiranjem demokracije, torej z njeno subjektivizacijsko funkcijo, v kateri lahko vsi potencialni člani neke skupnosti, ne glede na njihov status, aktivno participirajo v javni sferi, govorijo kot njeni enakovredni člani ter se tako učijo demokratičnih praks.

Ključne besede: dejavno državljanstvo, državljanska vzgoja, begunska kriza, Evropa, izobraževanje odraslih

\section{THE MEANING OF ACTIVE CITIZENSHIP AND CITIZENSHIP EDUCA- TION IN THE TIME OF MIGRATION AND REFUGEE CRISIS IN EUROPE - ABSTRACT}

The article examines the conceptualisation of citizenship education and active citizenship in adult education in the increasingly diverse and pluralistic European society, which is faced by a mass influx of migrants and refugees. The discussion embraces two concepts of citizenship education: the "citizenship as status" and "citizenship as a practice". The definition of the first originates from Habermas's notion of democracy and the public sphere, by which we demonstrate that citizenship education in the integrative education programmes is primarily associated with the adaptation of newcomers to the existing liberal democratic social order, i.e. with its socialization function. Contrary to this conceptualization of citizenship education and referring to the concepts of democracy and politics as developed by Mouffe and Rancière, we argue that citizenship education and active citizenship are significantly associated with the

Doc.dr. Borut Mikulec, Filozofska fakulteta Univerze v Ljubljani, borut.mikulec@ff.uni-lj.si 
practice of democracy, therefore with its subjectification function, in which all potential members of one community, regardless of their status, can actively participate in the public sphere, speak as its equal members and thus learn democratic practices.

Keywords: active citizenship, adult education, citizenship education, Europe, refugee crisis

\section{UVOD}

Niz aktualnih dogodkov izpričuje, da se v evropski, pa tudi slovenski družbi srečujemo z množičnim prihodom (oz. bolj prečkanjem teritorialnih mej v primeru Slovenije) beguncev in migrantov na staro celino, ki so na eni strani sprožili predvsem prevladujoče valove strahu, rasizma, ksenofobije, panike, populizma ter ponovne krepitve skrajnih desnih populističnih strank, na drugi pa tudi aktivacijo civilne družbe, v kateri številni samoorganizirani posamezniki in skupine skušajo lajšati položaj beguncev in migrantov, ki so se znašli v človeka nevrednih razmerah (Balibar, 2015; Kozinc, 2015a, 2015b). Čeprav je begunska kriza večplastna in ne omogoča enostavnih rešitev, saj odpira temeljna vprašanja, povezana s pravičnejšo družbeno ureditvijo, pravnim statusom (evropskega) državljanstva, enakostjo možnosti (pravica do dela, socialne in kulturne pravice) itd., pa lahko v ospredje postavimo vsaj dve ugotovitvi: prvič, da begunska kriza spreminja podobo Evrope, kot smo jo poznali, in drugič, da je izobraževanje (poleg zaposlovanja) tisti družbeni podsistem, ki naj bi pomembno oz. ključno pripomogel k uspešni integraciji beguncev in migrantov v evropsko skupnost (Balibar, 2015).

Vprašanja, povezana z migracijami, begunsko krizo, integracijo in vseživljenjskim izobraževanjem, niso ostala zanemarjena niti na področju izobraževanja odraslih tako v Evropi kot Sloveniji. V evropskem prostoru so raziskovalci opozorili na pomanjkljivosti integracijskih politik izobraževanja odraslih in vseživljenjskega učenja ter ob vse večjem pritoku prišlekov, predvsem v skandinavske in nemško govoreče evropske države, poudarili, da se integracijske politike osredotočajo predvsem na zaposljivost teh ljudi in večjo neodvisnost od socialnih transferjev: v ospredju so politike priznavanja kvalifikacij, vključevanja $\mathrm{v}$ formalno izobraževanje (priznavanje predhodno pridobljenega znanja, učenje jezika, pridobivanje novega znanja za udeležbo v bolje plačanih poklicih) ter dejavnega udejstvovanja na trgu dela (Webb, Hodge, Holford, Milana in Waller, 2016). Prav tako raziskovalci v migracijah ne vidijo grožnje, ampak slednje razumejo kot novo priložnost za Evropo, ob kateri lahko ta izrazi svojo humanistično skrb za človeka, saj je vsak človek najprej in predvsem človek (Kurantowicz, Olesen in Wildemeersch, 2014). Do podobnih ugotovitev so prišli tudi raziskovalci v Sloveniji, ko so poudarili, da pomenijo migranti za državo sprejema potencial na družbenokulturnem in ekonomskem področju ter da pot do uspešne integracije vodi prek vključitve migrantov v izobraževalni sistem in na trg dela (Vrečer in Mezgec, 2015). Prav tako pa je bil ob aktualni begunski krizi izražen poziv k družbeni refleksiji o še nezastavljenih vprašanjih, ki terjajo nove odgovore na širšem področju humanistike in družboslovja, od pedagogike in andragogike pa premislek o njuni 
vlogi v družbi, v kateri prevladujejo rasistične in diskriminatorne politike do beguncev in migrantov (Gregorčič, 2016). Ne nazadnje je o tem, kakšno vlogo naj prevzamejo delavci na področju vzgoje in izobraževanja ob vključevanju beguncev v slovensko družbo, na letošnjih Pedagoško-andragoških dnevih z naslovom Migracije in izobraževanje, ki jih je 26. januarja organiziral Oddelek za pedagogiko in andragogiko Filozofske fakultete Univerze v Ljubljani, potekala tudi javna razprava.

Izhajajoč iz tega razmisleka, nas bo v prispevku zanimalo vprašanje, kako razumeti in koncipirati državljansko vzgojo ter spodbujati dejavno državljanstvo v izobraževanju odraslih v vse bolj pluralni in raznoliki evropski družbi. Čeprav je bilo pri nas o dejavnem državljanstvu napisanih že kar nekaj razprav (npr. Benn, 1999; Cendon, 1999; Klemenčič, 1999; Kump, 2013; Mohorčič Špolar, 1999), pa dejavno državljanstvo in udejstvovanje »nedržavljanov«, torej migrantov in beguncev, v javni sferi (civilni družbi) še nista bili tematizirani z vidika izobraževanja odraslih. Zato bomo obravnavali dve pojmovanji državljanske vzgoje: (a) »državljanstvo kot status«, povezano s pravicami in dolžnostmi, ki so neločljive od pripadnosti določeni skupnosti (državi), gre torej za liberalnodemokratsko tradicijo državljanstva, ter (b) »državljanstvo kot prakso«, povezano z dejavnim udejstvovanjem v javnih prostorih civilne družbe, v katerih se lahko demokratične prakse izkusijo in doživijo kot priložnosti za učenje, gre torej za bolj republikansko tradicijo državljanstva, ki poudarja posameznikov angažma v javni razpravi o skupnem dobrem (Wildemeersch, 2014a; Wildemeersch in Vandenabeele, 2010). V tem kontekstu nas bo zanimalo zlasti vprašanje, kako lahko koncipiramo državljansko vzgojo in spodbujamo dejavno državljanstvo, razumljeno kot »prakso«, v kateri lahko sodelujejo vsi potencialni člani neke skupnosti, torej tudi migranti in begunci, in ne zgolj državljani, ki jim po statusu pripadajo pravice za takšno udejstvovanje. Pri tem bomo izhajali iz politične dimenzije izobraževanja, državljanske vzgoje in koncepta demokracije, ki je zavezan odprtemu prostoru za razpravo, pluralnosti mnenj, nestrinjanju, nerazumevanju, bojem in konfliktom, saj pluralnost, raznolikost in antagonizmi pomenijo raison d'être demokratičnih praks (Biesta, 2014; Koczanowicz, 2013).

Začeli bomo s predstavitvijo Habermasovega pojmovanja deliberativne demokracije in javne sfere ter nadaljevali s kritiko njegovega modela, kot sta jo razvila Chantal Mouffe in Jacques Rancière. Izhajajoč iz njunega pojmovanja »političnega«, bomo dokazovali tezo, da sta državljanska vzgoja in dejavno državljanstvo bistveno povezana s prakticiranjem demokracije, v kateri lahko vsi potencialni člani neke skupnosti aktivno participirajo in govorijo kot njeni enakovredni člani ter se tako učijo demokratičnih praks, pri čemer pa spoštujejo vrednote solidarnosti, enakosti in svobode vseh. Takšno pojmovanje političnega pa bo od nas prav tako terjalo, da premislimo emancipatorno politično naravo izobraževanja v radikalni tradiciji izobraževanja odraslih, kakor tudi opredelimo novo vlogo izobraževalcev odraslih pri spodbujanju dejavnega državljanstva in državljanske vzgoje, kar bomo storili v zaključnem delu prispevka. 


\section{HABERMASOVO POJMOVANJE DELIBERATIVNE DEMOKRACIJE, JAVNE SFERE IN DRŽAVLJANSTVA KOT STATUSA}

Delo Jürgena Habermasa (1996), ki zagovarja demokracijo kot prostor za premišljevanje, dialog in javno rabo uma za svobodne in enake državljane, pomeni dobro izhodiščno točko za razpravo o demokraciji in javni sferi. Javna sfera je ključni koncept demokracije, ki zagotavlja tako normativno osnovo za racionalno in kritično razpravo kakor tudi prostor za generiranje javnega mnenja, usmerjenega k doseganju skupnega razumevanja oz. soglasja o vseh pomembnih družbenih vprašanjih. Čeprav se to soglasje le redko doseže, kot priznava Habermas, pa je avtor prav tako prepričan, da ga je načeloma vedno mogoče doseči z vsakim dejanjem človeške komunikacije in da to velja tudi »za komunikacijo med tujci« (prav tam, str. 366). Javna sfera je prostor, v katerem ljudje (člani določene politične skupnosti) razpravljajo o zadevah skupnega pomena ter se seznanjajo s stališči drugih in se učijo o njih; gre torej za areno, v kateri se prek javne izmenjave argumentov ustvarja kolektivna volja ljudi, ki je podlaga za legitimnost političnih odločitev. Javna sfera je del civilne družbe, ki sestoji iz »spontano nastalih združenj, organizacij in gibanj « (prav tam, str. 367) ter ima pomembno vlogo pri zmanjševanju vpliva državne oblasti in kapitalistične ekonomije. Zato je po avtorjevem mnenju ključno, da ohranjamo »energično civilno družbo« (prav tam, str. 369), saj lahko le slednja zaščiti komunikacijsko strukturo javne sfere pred njenimi deformacijami, kakor tudi izvaja neposreden vpliv na politične odločitve; demokratičen sistem deluje dobro, le če civilna družba in javno mnenje vplivata na politike in zakone institucij odločanja (gl. tudi Fleming, 2002; Fraser, 2007; Karppinen, Moe in Svensson, 2008; Koczanowicz, 2013).

Sledeč Habermasu in kritični oz. radikalni tradiciji v izobraževanju odraslih, so si mnogi izobraževalci odraslih prizadevali identificirati prostore v civilni družbi, v katerih bi lahko potekalo kritično učenje, in sicer iz dveh razlogov: prvič zato, ker so v civilni družbi, osvobojeni dominacije državne oblasti in kapitalizma, prepoznali poglavitno mesto za učenje (Fleming, 2002), in drugič zato, ker so v izobraževanju odraslih prepoznali motor družbenih sprememb, ki lahko občutno pripomore k ohranjanju demokracije in vodi k emancipaciji, s tem ko se odrasli učijo načel demokratičnega razuma, dejavnega državljanstva in komunikativne akcije, kar naj bi vodilo h kontrahegemonskim praksam (Brookfield, 2010; Fleming in Murphy, 2010; Welton, 2001). Vendar kot vidimo danes, lahko kritično učenje v civilni družbi in »kontrahegemonske« prakse z lahkoto prevzamejo različna populistična ter skrajno desničarska ekstremistična gibanja (prim. Jelenc Krašovec, 2015, str. 58). »Radikalizirati se« pomeni danes predvsem prakticirati islamistični ekstremizem in terorizem; Islamska država Iraka in Levanta (ISIS) prav tako izvaja »kritično učenje« v civilni družbi, saj si prizadeva izobraziti muslimane, ki so bili zatirani, o vzrokih njihovega trpljenja in o iskanju rešitev zanj (Low, 2016). Temeljno vprašanje se zato glasi, kako vzpostaviti javno sfero kot prostor za prakticiranje demokracije in ne nasilnega ekstremizma.

Habermasov model deliberativne demokracije in javne sfere je bil deležen tudi kritik, ker je reproduciral idejo o homogeni nacionalni državi, poenostavil družbeno enotnost 
in dosego racionalnega soglasja ter ni ustrezno obravnaval pluralizma in odnosov moči v družbi (Fraser, 2007; Karppinen idr., 2008). Kot ugotavlja Fraserjeva (2007), je temeljni problem Habermasovega pojmovanja javne sfere $\mathrm{v}$ tem, da je javnost enačil z nacionalnostjo, državljanstvom in teritorijem, danes pa zaradi fenomenov migracij in multikulturnega značaja skupnosti (kot empiričnega dejstva) ta enačaj ne velja več. Današnje javne sfere so prej transnacionalne in niso vezane na nacionalno državljanstvo, zaradi česar avtorica sklene, da je javno mnenje legitimno le, če lahko vsi potencialni člani neke skupnosti participirajo v javni sferi »ne glede na svoje državljanstvo« (prav tam, str. 22).

Habermasovo pojmovanje državljanstva lahko umestimo v liberalnodemokratsko tradicijo, ki državljanstvo obravnava predvsem kot pravno kategorijo; ljudje, ki so se rodili na določenem teritoriju, avtomatično pridobijo status državljana te države (državljanstvo kot status), ta pa jim zagotavlja različno paleto državljanskih, socialnih in političnih pravic. Državljani (migranti, begunci), ki odidejo v tujo državo, morajo zato pridobiti državljanstvo te države prek pravnih postopkov, ki po navadi trajajo vrsto let (Wildemeersh, 2017). V povezavi z razumevanjem državljanstva kot statusa so se v liberalnodemokratskih družbah razvili tudi različni integracijski izobraževalni programi za prišleke, katerih bistvo je $\mathrm{v}$ tem, da morajo biti otroci in odrasli poučeni o temeljnih načelih liberalnodemokratskih družb ter da se morajo slednjim tudi brezpogojno prilagoditi, saj so ta načela v svoji abstraktni formulaciji onkraj razprave. Državljanska vzgoja tu opravlja predvsem svojo socializacijsko funkcijo in si prizadeva vzpostaviti »dobrega državljana«, čeprav soglasja o tem, kaj to pravzaprav pomeni, ni (Biesta, 2014, str. 6; Schugurensky, 2010, str. 114). A če obstaja konsenz o abstraktnih načelih in temeljnih liberalnodemokratskih vrednotah svobode, enakosti in solidarnosti, pa se pojavijo razhajanja in konflikti v praksi zaradi konkretnih družbenih norm (npr. različnih interpretacij uporabe naglavne rute, pravil oblačenja, odnosa med moškim in žensko ter institucije zakona, homoseksualnih odnosov itd.), zaradi česar se integracijski izobraževalni programi osredotočajo bodisi na neposredno poučevanje prišlekov o »pravilnem« razumevanju zahodnih vrednot in norm bodisi na dialog in »razumevanje « teh vrednot. Bolj specifično, osredotočajo se na formo teleološkega dialoga, katerega cilj je »udeležence v dialogu « pripeljati do vnaprej znanega točno določenega pravilnega odgovora, in sicer tako, da učitelj udeležence osvobodi njihove »lažne zavesti «. ${ }^{1}$ Še bolj konkretno, učitelj naj bi razsvetlil muslimanske ženske tako, da jim pokaže, kako so bile indoktrinirane v religijo, v njih prebudil načela razsvetljenstva ter jih na ta način popeljal na pot iz teme v svetlobo (Wildemeersh, 2017, str. 9-10).

V nadaljevanju si bomo, izhajajoč iz kritike Habermasovega modela demokracije, pogledali, kako sta demokracijo koncipirala Chantal Mouffe in Jacques Rancière ter kakšne izpeljave državljanske vzgoje in dejavnega državljanstva sledijo iz njunih pojmovanj demokratičnih praks.

1 Kot pravi Burbules (2000), vodi »fetišizacija dialoga«, to je razumevanje dialoga kot ključnega instrumenta za človeško emancipacijo - bodisi v obliki sokratske metode, Freirove pedagogike zatiranih bodisi Habermasovega iskanja konsenza - v izključevanje, »utišanje« in »normalizacijo« drugih kot drugačnih. 


\section{OD DELIBERATIVNE K AGONISTIČNI DEMOKRACIJI}

Mouffejeva (2005) razlikuje med družbenim in političnim; družbeno se nanaša na nabor praks in institucij, prek katerih se vzpostavi družbeni red, ki temelji na konsenzu med različnimi akterji, vključenimi v procese odločanja, medtem ko se politično nanaša na antagonistično in konfliktno naravo našega družbenega in političnega življenja. Izhajajoč iz te delitve, težava po avtoričinem mnenju nastane takrat, ko negiramo politično, zaradi česar liberalnodemokratska ureditev ne more zaobjeti pluralistične in konfliktne narave našega sveta. V nasprotju s Habermasom si avtorica prizadeva za vzpostavitev dinamične agonistične javne sfere, v kateri se lahko soočijo različni hegemonski politični projekti (prav tam, str. 3). Izhajajoč iz družbenega pluralizma, ki ga razume kot pripoznanje neizogibnega konflikta, avtorica prav tako poudari, da mora v družbi obstajati »neka vrsta skupne vezi med strankami v konfliktu« (prav tam, str. 20), da slednje ne bi uničile politične skupnosti. Antagonizmi, v katerih sta dve strani, »mi« in »oni«, sovražniki brez skupnih temeljev, se morajo preoblikovati v razmerje »agonizma «, torej v razmerje med nasprotniki (tekmeci), ki kljub konfliktom in neskladjem v svojih stališčih prepoznavajo drug drugega kot legitimnega udeleženca v skupnem političnem prostoru (prav tam). Naloga demokracije je tako spremeniti antagonistična razmerja v agonistična, saj so neskladja, konflikti in razlike sestavni del demokracije. A če po eni strani demokracija zahteva »spopad legitimnih demokratičnih političnih pozicij« (prav tam, str. 30), to še ne pomeni, da demokracija terja pluralizem brez kakršnihkoli omejitev. Kot pojasnjuje avtorica, pluralizem terja razlikovanje med zahtevami, ki jih je treba sprejeti kot del agonistične razprave, in tistimi, ki jih je treba izključiti, saj demokratična družba tistih, ki ogrožajo njene temeljne institucije, ne more obravnavati kot legitimne nasprotnike oz. tekmece (prav tam, str. 120).

Temeljna poanta agonistične demokracije, razumljene kot oblike »konfliktnega konsenza«, je torej v tem, da slednja zagotovi skupni simbolni prostor, v katerem lahko poteka agonistična razprava med nasprotniki, ki spoštujejo »etično-politične vrednote svobode in enakosti za vse« (prav tam, str. 121), a ne soglašajo o njihovem pomenu, interpretacijah in implementaciji. V agonistični demokraciji, ki je projekt radikalne demokracije, zato nismo soočeni zgolj s pluralnostjo resnic, ki so v nenehnem medsebojnem konfliktu, ampak tudi z demokratičnim redom, ki ni nespremenljiv, temveč ga je mogoče izzvati, saj ni dan enkrat in za vedno in je lahko tudi nepopoln. Migranti in begunci lahko tako po eni strani pomenijo posameznike in skupine, ki stojijo zunaj demokratičnega reda, če nasprotujejo njegovim temeljnim vrednotam, po drugi strani pa lahko pokažejo na nepopolno naravo določene demokratične ureditve in opozarjajo evropske demokracije na možnosti vzpostavitve drugačnega, pravičnejšega demokratičnega reda (Biesta, 2014, str. 3-4).

Če apliciramo pojmovanje agonistične demokracije na področje izobraževanja odraslih, lahko vidimo, da demokracija prvenstveno ni prostor konsenza, ampak nesoglasja. V tem kontekstu bi morala biti državljanska vzgoja in dejavno državljanstvo zavezana aktivnemu udejstvovanju v kolektivnih razpravah v javni sferi, ki jih označuje pluralizem nesoglasij in razlik, akcij in odločanja, saj se lahko prav v slednjih udeleženci učijo demokratičnih 
praks in prakticiranja demokracije. Državljanska vzgoja v agonističnem pojmovanju demokracije torej ni pogojena s članstvom v določeni skupnosti, v kateri bi se morali begunci, prosilci za azil in migranti najprej prilagoditi (asimilirati) obstoječemu družbenopolitičnemu redu in izbrisati svojo drugačnost, da bi lahko participirali v javni sferi, ampak je razumljena kot demokratična praksa in prakticiranje demokracije, kot eksperiment, $v$ katerem vsi potencialni člani neke skupnosti lahko aktivno participirajo, govorijo in izražajo svoja mnenja v odprtem javnem prostoru, pri čemer pa spoštujejo enakost in svobodo vseh (Biesta, 2014; Wildemeersch, 2014a; Wildemeersch in Vandenabeele, 2010).

\section{DEMOKRACIJA KOT POLITIKA SUBJEKTIVIZACIJE}

V nasprotju s Habermasovim pojmovanjem dialoga in deliberativne demokracije Rancière (1999) ugotavlja, da je nerazumevanje temeljno načelo demokracije in demokratičnih praks. Kot pravi avtor, nerazumevanje »ni konflikt med nekom, ki pravi belo, in drugim, ki pravi črno. Je konflikt med nekom, ki pravi belo, in drugim, ki prav tako pravi belo, a s tem ne razume iste stvari« (prav tam, str. X). Nerazumevanje je nesporazum, ki temelji na odnosu moči: med bogatim in revnim, ki se sicer bojujeta za bolj enakomerno porazdelitev dobrin, a ta boj ne poteka »za isto mizo«, med delavstvom in buržoazijo, saj je poklic delavca, da dela, in buržoazije, da misli itd. (Doerr, 2013). V nasprotju z iskanjem racionalnega konsenza Rancière (1999) izhod iz zagate nerazumevanja vidi v politiki prekinitve in vrnitvi politike. Avtor razlikuje med družbenim (»policijskim«) redom, ki je povezan z organizacijo oblasti in sistemom za legitimiranje ter distribucijo položajev in vlog v družbi, ki nikoli ne morejo biti popolnoma enaki, ter politiko, ki pomeni prekinitev obstoječega družbenega reda. Politika je tako del tistih, »ki nimajo deleža« in so sposobni premakniti »telo iz kraja, ki jim je dodeljen«, ter s tem narediti »vidno, kar ne bi smelo biti vidno « (prav tam, str. 30). Kot primer politike Rancière (2012) navaja aktivnosti delavcev v 19. stoletju, ki so, namesto da bi spali, noči preživljali tako, da so poskušali vstopiti v svet, ki naj ne bi bil njihov: v svet pisanja, razmišljanja, komponiranja in filozofiranja. Tako so se osvobodili od vsakodnevnega dela in dokazali, da lahko mislijo in suvereno soočajo mnenja s tistimi, ki so imeli privilegij mišljenja. Če delavski razred ni želel biti izključen iz javne sfere ali biti »vključen kot izključen«, kot so bili npr. ženske, otroci in sužnji v antični Grčiji, si je moral vzeti čas za diskusije, uporabiti jezik »drugega« (buržoazije) ter dokazati svojo enakost.

Politika torej vznikne, ko se družbeni red sreča s procesom doseganja enakosti; opredeljuje jo nabor praks, ki jih vodita predpostavki o enakosti med vsemi govorečimi bitji in o verifikaciji te enakosti (Rancière, 1999, str. 30). Politika, opredeljena na ta način, nima nič skupnega s Habermasovim pojmovanjem demokracije oz. z obljubljeno "pravo« demokracijo, ki naj bi prišla v prihodnjem času, ampak je ta vedno že tu, je del vsakdanjih praks ter enkratnega srečanja med enakostjo in neenakostjo (prav tam, str. 99). Demokracija je politika subjektivizacije, ki ne pomeni samo prekinitve obstoječega družbenega reda, upoštevajoč enakost vseh, ampak tudi preoblikovanje tega reda, v katerem vznikajo nove oblike delovanja in nove identitete (Biesta, 2014, str. 5). Subjektivizacija tako vznikne, 
ko se zatirane skupine vzpostavijo kot politični subjekti z novo identiteto, ki predhodno ni obstajala, dokažejo svojo enakost z dominantnimi skupinami in so zmožni spremeniti odnose moči skozi akcijo.

Če apliciramo Rancièrovo pojmovanje politike in demokracije na področje izobraževanja odraslih, lahko ugotovimo, da demokracija pri njem ni povezana s posebnim družbenim redom, ampak s trenutki, ko lahko nekdo prekine in spremeni obstoječi družbeni red, da bi dosegel enakost vseh. Na ta način lahko mnoštvo glasov šele začne obstajati. Državljanska vzgoja, konceptualizirana kot politična subjektivizacija, je torej povezana z eksperimentom demokracije in procesom transformacije. Demokratične vzgoje in dejavnega državljanstva se učimo skozi participacijo v demokratičnih praksah, zaradi česar je temeljni izziv državljanske vzgoje krepitev državljanskega delovanja v javni sferi. Ker udeleženci ne potrebujejo nobenega posebnega znanja, da bi participirali, bili obravnavani enako in se spraševali o samoumevnih predpostavkah, se lahko vsakdo pridruži temu eksperimentu demokracije (Biesta, 2014, Biesta in Cowell, 2016; Wildemeersch, 2014b).

\section{SKLEPNE MISLI}

Z begunsko krizo je na stotisoče beguncev vstopilo v Evropo, kar pomeni, da so se kljub morebitnemu nasprotovanju dela javnosti otroci vključili $v$ šole, odrasli pa v institucije izobraževanja odraslih v različnih evropskih državah. V slednjih naj bi se begunci učili jezika in se seznanili s kulturo države gostiteljice ter bili ob tem deležni spoštovanja do lastne kulture. Ta izziv obvezuje praktike in raziskovalce izobraževanja odraslih, da med drugim premislijo o vlogi državljanske vzgoje $\mathrm{v}$ integracijskih izobraževalnih programih za begunce in migrante, kakor tudi o pomenu prakticiranja dejavnega državljanstva $\mathrm{v}$ sklopu pobud neformalnega izobraževanja ter priložnostnega učenja $v$ javni sferi.

Poziv k aktivni vlogi izobraževanja odraslih v begunski krizi je prišel tudi od Evropskega združenja za izobraževanje odraslih, kjer opozarjajo, da lahko ponudniki izobraževanja odraslih pomagajo beguncem pri lažjem vključevanju v kulturo in življenje v novi državi s tem, da ponujajo jezikovne tečaje, tečaje državljanske vzgoje, jim pomagajo z informacijami o njihovih možnostih in pravicah, organizirajo medkulturna srečanja za begunce in domačine ter v sklopu neformalnega izobraževanja spodbujajo dejavno državljanstvo (EAEA, 2015).

Kljub humanistični retoriki temeljna zagata integracijskih izobraževalnih programov in propagiranja dejavnega državljanstva v liberalnodemokratskih družbah ostaja v tem, da si prvenstveno prizadevajo prilagoditi migrante in begunce temeljnim evropskim normam in vrednotam ter s tem ohraniti (navidezno) ontološko varnost v družbi tveganja in v času vse večje nestabilnosti (Bauman, 2013; Wildemeersch, 2017). V tem smislu se integracijski izobraževalni programi naslanjajo predvsem na državljansko vzgojo, ki je povezana z razumevanjem državljanstva kot statusa in posledično s posredovanjem znanja za socializacijo odraslih v obstoječ demokratični družbenopolitični red. Čeprav je ta konceptualizacija državljanske vzgoje pomembna, saj sloni na liberalnodemokratskih 
vrednotah svobode, enakosti in solidarnosti, torej vrednotah, ki tvorijo ustavno podlago evropskih demokratičnih družb, pa ima tudi svoje omejitve in pomanjkljivosti, saj deluje predvsem kot orodje za prilagajanje vrednotam in normam zahodnih družb (vključuje zgolj socializacijsko funkcijo državljanske vzgoje), kakor tudi vzpostavlja normo o tem, kaj pomeni biti (evropski) državljan, ter izključuje vsakega, ki ne dosega predpisane norme. V kontekstu koncipiranja dejavnega državljanstva ter v luči terorističnih napadov in begunske krize v Evropi nas tudi Žižek (2015a, 2015b) opozarja, da evropske demokratične družbe danes ne potrebujejo še več vztrajanja na »dialogu kultur«, ampak potrebujejo predvsem »solidarnost bojev« agonistične demokracije; v kontekstu današnje konsenzualne liberalne demokracije in dialoga med kulturami smo priča izključitvi beguncev in migrantov iz kakršnekoli javne razprave in medijev. Nimajo niti glasu niti prostora, da bi lahko spregovorili v evropski javni sferi. Še več, nekdo (dobri beli liberalci) vedno govori v njihovem imenu.

Poleg koncepta državljanstva kot statusne kategorije smo v prispevku proučevali tudi nasprotno razumevanje državljanstva in državljanske vzgoje kot aktivnosti oz. prakse, ki ni povezana s predhodno podeljenimi pravicami ali nujno pridobljenim znanjem za participacijo v družbi, ampak s prakso, v kateri lahko vsi potencialni člani neke skupnosti ne glede na svoj (pravni) status aktivno participirajo in govorijo kot njeni enakovredni člani ter se tako učijo demokratičnih praks (torej s subjektivizacijsko funkcijo državljanske vzgoje). Proučevali smo pomen priložnostnega učenja in neformalnega izobraževanja v javni sferi za učenje demokratičnih praks in demokracije (gl. tudi Jelenc Krašovec, 2015), saj se aktivne demokracije »človek nauči iz prakse« (Benn, 1999, str. 51).

Pri tem smo posebno pozornost namenili pojmovanju demokracije. Izhajali smo iz Habermasovega pojmovanja demokracije in javne sfere, ki to razume kot prostor za premišljevanje, dialog in javno rabo uma svobodnih in enakih državljanov, kakor tudi poudarili njegova prizadevanja za vzpostavitev javne sfere in civilne družbe kot temeljnega prostora za učenje - učenje demokratičnega razuma, dejavnega državljanstva in komunikativne akcije. A kot so zaznali Habermasovi kritiki, je slednji teorijo javne sfere in demokracije gradil na predpostavkah homogene nacionalne države, družbene enotnosti in na racionalnem konsenzu, danes pa smo priča družbeni realnosti, ki je bliže konfliktnim situacijam ter družbenemu pluralizmu in raznolikostim. V nasprotju z iskanjem in doseganjem racionalnega konsenza v javni sferi smo, izhajajoč iz pojmovanja političnega pri Mouffejevi in Rancièru, postavili v ospredje tezo, da je bistvo demokracije in demokratičnih praks v pluralnosti mnenj in resnic, nerazumevanju ter konfliktih. Mouffejeva vidi demokracijo kot obliko »konfliktnega konsenza«, ki naj bi zagotovil skupni javni prostor, v katerem lahko poteka agonistična razprava med vsemi potencialnimi člani skupnosti o njihovih hegemonskih projektih, a ob spoštovanju demokratičnih vrednot svobode, enakosti in solidarnosti, pri čemer pa ni nujno, da nasprotniki medsebojno soglašajo o njihovem pomenu. Rancièr pa demokracije ne vidi kot specifičnega družbenega reda ali načina življenja, ampak mu demokracija pomeni trenutke, ki lahko prekinejo in preoblikujejo obstoječ družbeni red z namenom vzpostavitve enakosti vseh ter oblikovanja novih načinov delovanja in identitet. 
Demokratično državljanstvo bi torej morali razumeti kot demokratično prakso, v kateri lahko vsi potencialni člani neke družbe, vključno z migranti in begunci, aktivno participirajo in izražajo svoja mnenja kot enakovredni govorci v javni sferi ob spoštovanju temeljnih vrednot enakosti in svobode vseh njenih članov. Prav tako bi moralo biti migrantom in beguncem omogočeno, da samostojno izražajo svoja mnenja $v$ javni sferi evropskih demokratičnih družb (enako kot njenim državljanom), saj je javna sfera prostor, kjer se njihov emancipatorni boj v družbenih vprašanjih javnega pomena, kakor tudi naše učenje (učenje Evropejcev) o njihovi drugačnosti šele lahko začne, čeprav demokratične metode delovanja niso nujno zagotovilo za uspeh takšnih prizadevanj. V tem kontekstu bi morali izobraževalci odraslih spodbujati nastanek javnih (agonističnih) prostorov in si prizadevati za njihovo ohranjanje, saj slednji po eni strani lahko omogočijo odpor proti kolonizaciji javne sfere s strani privatnih in tržnih mehanizmov, po drugi strani pa zagotovijo pluralnost glasov vseh udeležencev ter s tem nastanek novega znanja, idej, perspektiv in možnih rešitev. Pri tem pa je ključno, da izobraževalci odraslih ne delujejo kot »razsvetljeni intelektualci«, ki razpolagajo z znanjem o »lažni zavesti« migrantov in beguncev ter pravilnimi odgovori in rešitvami, kako naj bi slednji živeli v evropskih demokratičnih družbah, kar je bil pogosto nekakšen »recept«, predpisan za emancipacijo marginaliziranih družbenih skupin, ki ga najdemo v kritični oz. radikalni tradiciji izobraževanja odraslih, ki črpa pretežno iz idej Habermasa in/ali Freira (Morrow in Torres, 2002).

Kot smo pokazali v prispevku, so ideje, ki jih razvijata Mouffejeva in Rancièr, izzvale tudi prevladujoče razumevanje in vlogo izobraževalcev odraslih v radikalni tradiciji izobraževanja odraslih, ki je povezana $\mathrm{z}$ ohranjanjem demokracije in emancipatornim učenjem; izobraževalci odraslih so tako pozvani, da premislijo o svojih emancipatornih izobraževalnih prizadevanjih. In sicer, če Rancièrove ideje apliciramo na izobraževanje odraslih, potem ugotovimo, da temeljna vloga izobraževalcev odraslih pri državljanski vzgoji ni v tem, da pripravljajo in izvajajo posebne programe za migrante in begunce, ampak da odpirajo javno sfero oz. javni prostor za vse člane skupnosti ter jih motivirajo za delovanje, saj se lahko na ta način vzpostavijo demokratični trenutki, ki prekinejo in preoblikujejo obstoječ (nedemokratični) družbeni red ter vzpostavijo emancipirane politične subjekte z novo identiteto. Izobraževalec odraslih tako ne deluje niti kot inštruktor niti kot spodbujevalec učenja ali »emancipatorna avtoriteta «, ki učečemu se omogoči uvid v resnično človeško eksistenco, ampak kot nekdo, ki si prizadeva za prekinitev družbeno samoumevnih predpostavk, intervenira v družbeni red ter vzpostavi demokratične trenutke nesoglasja. Podobno tudi ideje, ki jih razvija Mouffejeva, od izobraževalcev odraslih terjajo, da ti vzdržujejo odprte javne prostore, v katerih lahko poteka legitimna agonistična razprava o hegemonskih pogledih različnih skupin v družbi pod okriljem demokratičnih vrednot enakosti in svobode vseh, saj lahko ta vodi k demokratičnemu preoblikovanju skupnosti in emancipaciji njenih članov.

Če lahko izobraževalci odraslih pripomorejo k vzpostavitvi aktivne civilne družbe, odprtih javnih prostorov in širijo prostor razprave, potem lahko državljani, migranti in begunci $\mathrm{v}$ njih participirajo, izražajo svoja mnenja in poglede kot medsebojno enakovredni ter se 
učijo demokratičnih praks, ki imajo potencial, da ustvarijo nove načine delovanja, nove identitete, novo znanje ter nove načine skupnega sobivanja.

\section{LITERATURA}

Balibar, E. (2015). Evropa in begunci: demografska širitev. Časopis za kritiko znanosti, 43(262), 207-215. Bauman, Z. (2013). Learning to Walk on Quicksand: Lifelong Learning and Liquid Life. V P. Mayo (ur.), Learning with Adults (str. 9-18). Rotterdam: Sense Publishers.

Benn, R. (1999). Izobraževanje za aktivno državljanstvo. Andragoška spoznanja, 5(4), 48-51.

Biesta, G. (2014). Learning in Public Places: Civic Learning for the Twenty-First Century. V G. Biesta,

M. D. Bie in D. Wildemeersch (ur.), Civic Learning, Democratic Citizenship and the Public Sphere (str. 1-11). Springer: Dordrecht.

Biesta, G. in Cowell, G. (2016). Cities, citizenship and civic learning: Introduction to the special edition. Policy Futures in Education, 14(4), 427-430.

Brookfield, S. D. (2010). Learning Democratic Reason: The Adult Education Project of Jürgen Habermas. V M. Murphy in T. Fleming (ur.), Habermas, Critical Theory and Education (str. 125-136). New York in London: Routledge.

Burbules, N. C. (2000). The Limits of Dialogue as a Critical Pedagogy. V P. P. Trifonas (ur.), Revolutionary Pedagogies: Cultural Politics, Instituting Education, and the Discourse of Theory (str. 251-273). New York in London: Routledge.

Cendon, E. (1999). Hannah Arendt in aktivno državljanstvo. Andragoška spoznanja, 5(4), 52-54.

Doerr, N. (2013). Between Habermas and Rancière: The Democracy of Political Translation. Pridobljeno s http://eipcp.net/transversal/0613/doerr/en.

EAEA. (2015). Izjava EAEA o vlogi izobraževanja odraslih v begunski krizi. Pridobljeno s https:// ec.europa.eu/epale/sl/content/izjava-eaea-o-vlogi-izobrazevanja-odraslih-v-begunski-krizi.

Fleming, T. (2002). Habermas on Civil Society, Lifeworld and System: Unearthing the Social in Transformation Theory. Pridobljeno s http://www.tcrecord.org/Content.asp?ContentID=10877.

Fleming, T. in Murphy, M. (2010). Taking Aim at the Heart of Education: Critical Theory and the Future of Learning. V M. Murphy in T. Fleming (ur.), Habermas, Critical Theory and Education (str. 201-207). New York in London: Routledge.

Fraser, N. (2007). Transnationalizing the Public Sphere: On the Legitimacy and Efficacy of Public Opinion in a Post-Westphalian World. Theory, Culture \& Society, 24(4), 7-30.

Gregorčič, M. (2016). Uvodnik: Ali je potrebno premisliti antirasistične perspektive za izobraževanje?. Andragoška spoznanja, 22(1), 3-6.

Habermas, J. (1996). Between Facts and Norms. Contributions to a Discourse Theory of Law and Democracy. Cambridge: The MIT Press.

Jelenc Krašovec, S. (2015). Pomen javnih prostorov za druženje in učenje starejših ljudi.

Sodobna pedagogika, 66(3), 52-68.

Karppinen, K., Moe, H. in Svensson, J. (2008). Habermas, Mouffe and political communication: A case for theoretical eclecticism. Javnost, 15(3), 5-22.

Klemenčič, S. (1999). Izobraževanje odraslih za aktivno državljanstvo - nujnost ali utopija? Uvodnik. Andragoška spoznanja, 5(4), 3-4.

Koczanowicz, L. (2013). Education for Resistance, Education for Consensus?: Non-Consensual Democracy and Education. V T. Szkudlarek (ur.), Education and the Political. New Theoretical Articulations (str. 25-39). Rotterdam: Sense Publishers. 
Kozinc, N. (2015a). Moč nemočnih. Časopis za kritiko znanosti, 43(262), 199-203.

Kozinc, N. (2015b). Dehumanizacija za rezalno žico: Uvod. Časopis za kritiko znanosti, 43(262), 245-249.

Kump, S. (2013). Izobraževanje odraslih v evropskem letu državljanov. Andragoška spoznanja, 19(1), 8-19.

Kurantowicz, E., Olesen, H. S. in Wildemeersch, D. (2014). Editorial: a human being is a human being is a human being is a human being-the issue of migration in Europe and the responses of adult education. European Journal for Research on the Education and Learning of Adults, 5(2), 145-148.

Low, R. (2016). Making up the Ummah: The rhetoric of ISIS as public pedagogy. Review of Education, Pedagogy, and Cultural Studies, 38(4), 297-316.

Mohorčič Špolar, V. (1999). Vsebina in pomen pojma državljanstvo. Andragoška spoznanja, 5(4), 5-12.

Morrow, R. A. in Torres, C. A. (2002). Reading Freire and Habermas. Critical Pedagogy and transformative Social Change. New York in London: Teachers College, Columbia University.

Mouffe, C. (2005). On the Political. Abingdon: Routledge.

Rancière, J. (1999). Disagreement: Politics and Philosophy. Minneapolis: University of Minnesota Press.

Rancière, J. (2012). Proletarian Nights. The Workers Dream in Nineteenth-Century France. London in New York: Verso.

Schugurensky, D. (2010). Citizenship and Immigrant Education. V P. Peterson, E. Baker in B. McGaw (ur.), International Encyclopedia of Education: Third Edition (str. 113-119). Oxford: Elsevier Ltd.

Vrečer, N. in Mezgec, M. (2015). Uvodnik: Medkulturnost v izobraževanju odraslih. Andragoška spoznanja, 21(3), 3-6.

Webb, S., Hodge, S., Holford, J., Milana, M. in Waller, R. (2016). Refugee migration, lifelong education and forms of integration. International Journal of Lifelong Education, 35(3), 213-215.

Welton, M. (2001). Civil Society and the public sphere: Habermas's recent learning theory. Studies in the Education of Adults, 33(1), 20-34.

Wildemeersch, D. (2014a). Displacing Concepts of Social Learning and Democratic Citizenship. V G. Biesta, M. D. Bie in D. Wildemeersch (ur.), Civic Learning, Democratic Citizenship and the Public Sphere (str. 15-28). Springer: Dordrecht.

Wildemeersch, D. (2014b). Adult and community education in complex societies: reconsidering critical perspectives. International Journal of Lifelong Education, 33(6), 821-831.

Wildemeersch, D. (2017, pred tiskom). Opening spaces of conversation: citizen education for newcomers as a democratic practice. International Journal of Lifelong Education.

Wildemeersch, D. in Kurantowicz, E. (2011) Editorial: Adult education and the community. European Journal for Research on the Education and Learning of Adults, 2(2), 129-133.

Wildemeersch, D. in Vandenabeele, J. (2010). Issues of citizenship: coming-into-presence and preserving the difference. International Journal of Lifelong Education, 29(4), 487-502.

Žižek, S. (2015a). In the Wake of Paris Attacks the Left Must Embrace Its Radical Western Roots. Pridobljeno s http://inthesetimes.com/article/18605/breaking-the-taboos-in-the-wake-of-paris-attacksthe-left-must-embrace-its.

Žižek, S. (2015b). The Need to Traverse the Fantasy. Pridobljeno s http://inthesetimes.com/article/18722/ Slavoj-Zizek-on-Syria-refugees-Eurocentrism-Western-Values-Lacan-Islam. 